\title{
Antibodies against vesicular stomatitis virus in horses from southern, midwestern and northeastern Brazilian States
}

\author{
Anticorpos contra o vírus da estomatite vesicular em equinos \\ de Estados das regiões sul, centro-oeste e nordeste do Brasil
}

\author{
Vinícius Leobet Lunkes ${ }^{I}$ Alexandre Alberto Tonin ${ }^{I}$ Gustavo Machado ${ }^{I I}$ Luis Gustavo Corbellini ${ }^{I I}$ \\ Gustavo Nogueira Diehl ${ }^{\text {III }}$ Lucila Carboneiro dos Santos ${ }^{\text {III }}$ Camila de Sousa Bezerra ${ }^{\text {IV }}$ \\ Sérgio Santos de Azevedo ${ }^{I V}$ Nebson Fernandes Pequenov ${ }^{V}$ Adriana Moraes da Silva ${ }^{\text {VI }}$ \\ Rudi Weiblen ${ }^{I}$ Eduardo Furtado Flores $^{I^{*}}$
}

\section{ABSTRACT}

Vesicular stomatitis virus (VSV) is the agent of a vesicular disease that affects many animal species and may be clinically confounded with foot-and-mouth disease in ruminant and swine. Horses are especially susceptible to VSV and may serve as sentinels for virus circulation. The present study investigated the presence of neutralizing antibodies against VSV Indiana III (VSIV-3) in serum samples of 3,626 horses from six states in three Brazilian regions: Southern $(R S, n=$ 1,011), Midwest (GO/DF, $n=1,767)$ and Northeast $(P B, P E, R N$ and $C E, n=848)$ collected between 2013 and 2014. Neutralizing antibodies against VSIV-3 (titers $\geq 40$ ) were detected in 641 samples (positivity of $17.7 \%$; $\left.C_{950}: 16.5-19.0 \%\right)$, being 317 samples from $C E\left(87.3 \% ; C_{950}\right.$; 83.4-90.5\%); 109 from $R N\left(65.7 \%\right.$; $\left.\mathrm{CI}_{950}: 57.8-72.7 \%\right) ; 124$ from $P B$ (45.4\%; $\left.\mathrm{CI}_{95 \%}: 39.4-51.5 \%\right) ; 78$ from $\mathrm{GO} / \mathrm{DF}\left(4.4 \% ; \mathrm{CI}_{95 \%}: 3.5-5.5 \%\right)$ and nine samples of $R S\left(0.9 \% ; C I_{950}: 0.4-1.7 \%\right)$. Several samples from the Northeast and Midwest harbored high neutralizing titers, indicating a recent exposure to the virus. In contrast, samples from $R S$ had low titers, possibly due to a past remote exposure. Several positive samples presented neutralizing activity against other VSV serotypes (Indiana I and New Jersey), yet in lower titers, indicating the specificity of the response to $V S I V-3$. These results demonstrated a relatively recent circulation of VSIV-3 in northeastern Brazilian States, confirming clinical findings and demonstrating the sanitary importance of this infection.

Key words: serology, differential diagnosis, foot-and-mouth disease, zoonosis, vesicular disease.

RESUMO

$O$ vírus da estomatite vesicular (vesicular stomatitis virus, VSV) é o agente de doença vesicular que afeta várias espécies e que, em suinos e ruminantes, é clinicamente confundivel com a febre aftosa. Os equinos são particularmente susceptiveis ao VSV, servindo de sentinelas para a circulação viral. O presente trabalho investigou a presença de anticorpos neutralizantes contra o VSV Indiana III (VSIV-3) em amostras de soro de 3626 equinos de seis estados das regiões Sul (RS, $n=1011)$, Centro-oeste (GO e DF, $n=1767)$ e Nordeste (PE, PB, RNe CE, $n=848)$, coletadas entre 2013 e 2014. Anticorpos neutralizantes contra o VSIV-3 em titulos iguais ou superiores a 40 foram detectados em 641 amostras $\left(17,7 \%\right.$; IC $\left.{ }_{95 \%}: 16,5-19,0 \%\right)$, sendo 317 do CE (positividade de 87,3\%; IC $: 83,4-90,5 \%) ; 109$ do $R N(65,7 \%$; IC $: 57,8-72,7 \%)$; 124 da PB (45,4\%; IC 95\% $_{3}$ 39,4-51,5\%); 78 de GO/DF (4,4\%; IC ${ }_{95 \%}$ : $3,5-5,5 \%)$ e em nove amostras do $R S\left(0,9 \%\right.$; IC $\left.C_{950}: 0,4-1,7 \%\right)$. Uma parcela das amostras dos estados do Nordeste e Centro-oeste apresentou altos títulos neutralizantes, indicando exposição recente ao vírus. Já as amostras do RS apresentaram titulos baixos de anticorpos, indicando provável exposição temporalmente remota. Quando testadas contra outros sorotipos do VSV (Indiana I e New Jersey), várias amostras apresentaram atividade neutralizante, porém em títulos muito inferiores, indicando a especificidade dos anticorpos para o VSIV-3. Esses resultados demonstram circulação relativamente recente do VSIV-3 em várias regiões do Brasil, sobretudo em estados do Nordeste, confirmando relatos clínicos e demonstrando a importância sanitária dessa infecção.

Palavras-chave: sorologia, diagnóstico diferencial, febre aftosa, zoonose, doença vesicular.

\section{INTRODUCTION}

Vesicular stomatitis virus (VSV) is a viral agent belonging to the order Mononegavirales,

\footnotetext{
IDepartamento de Medicina Veterinária Preventiva, Universidade Federal de Santa Maria (UFSM), 97105-900, Santa Maria, RS, Brasil. E-mail: eduardofurtadoflores@gmail.com. "Corresponding author.

IILaboratório de Epidemiologia Veterinária, Faculdade de Veterinária, Universidade Federal do Rio Grande do Sul (UFRGS), Porto Alegre, RS, Brasil.

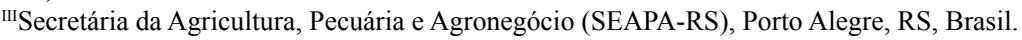

IV Unidade Acadêmica de Medicina Veterinária (UAMV), Centro de Saúde e Tecnologia Rural (CSTR), Universidade Federal de Campina Grande (UFCG), Patos, PB, Brasil.

VLaboratório Veterinária Diagnóstico Ltda, Catolé do Rocha, PB, Brasil.

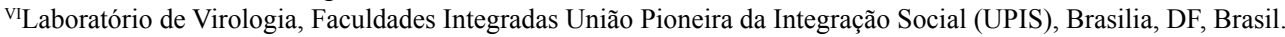
Received 08.10.15 Approved 02.22.16 Returned by the author 05.05.16
} CR-2015-1135.R1 
family Rhabdoviridae, genus Vesiculovirus. Besides its economical importance for the livestock, VSV represents a sanitary threat since it causes a disease that is clinically similar to foot and mouth disease in cattle and pigs (RIET-CORREA et al., 1996). VSV naturally infects a variety of mammals including horses, cattle, swine, wild mammals and man. VSV infection is endemic in the Americas and seems to be restricted to western hemisphere (LETCHWORTH et al., 1999). The disease is characterized by the development of vesicular lesions in mouth, tongue, teats and coronary bands of cattle, horses and pigs (RIET-CORREA et al., 1996). In most cases, the disease is self-limiting and the clinical course lasts approximately two to three weeks (REIS JR et al., 2009).

VSV isolates belong to two antigenically distinct serogroups: New Jersey (VSNJV) and Indiana (VSIV). Viruses of the VSNJV serogroup are disseminated in the southern-central United States. Serogroup VSIV contains three subtypes: Indiana I (VSIV-1- classical strains), Indiana II (VSIV-2 Cocal and Argentina) and Indiana III (VSIV-3 - Alagoas). Subtypes VSIV-2 and VSIV-3 have been occasionally isolated in Brazil, being the serotype VSIV-3 more restricted to the northeastern States (CARGNELUTTI et al., 2014). According to the ICTV (2014), there are the least 20 additional serotypes to be characterizated.

Vesicular stomatitis (VS) usually presents a seasonal pattern, whose incidence is usually higher in summer or in rainy seasons (MASON et al., 1978; OIE, 2010). This behavior has led to the hypothesis of dissemination by winds, birds and insect vectors (TESH et al., 1970). In this sense, the virus has been isolated from mosquitoes Phlebotomus and Aedes, indicating their possible role in virus transmission (HAYEK et al., 1998). According to OIE (2010), horses are particularly susceptible to VSV infection compared to cattle and pigs. Animal gathering in fairs, races, artificial insemination centers and other events seem to facilitate virus spread among susceptible animals (OKUDA et al., 2003).

VS in clinically undistinguishable from foot-and-mouth disease (FMD), making critical its prompt differential diagnosis. VS diagnosis may be performed by virus isolation or serological tests as virus-neutralization (VN), immunoenzimatic assays and complement-fixation (FERRIS \& DONALDSON, 1988; ALONSO FERNANDEZ et al., 1991).

In Brazil, positive serology to VSV has been detected in several states and different animal species. By comparing two serological tests,
ALLENDE \& GERMANO (1993) analyzed 305 cattle, horse and pig sera, detecting 300/305 (98.40\%) samples containing VN antibodies to VSIV-3. CUNHA et al. (2009) found that $21 \%$ of samples were positive to VSIV-2 (Cocal) and 5\% to VSIV-3 (Alagoas) in the São Paulo State.

VSV was fist isolated in Brazil in 1964, in Alagoas State, from sick horses and named VSIV-3 Alagoas, due to differences in serogroups VSIV1 and VSIV-2 (ANDRADE et al., 1980). In Minas Gerais, ARAÚJO et al. (1977) reported the isolation of serotype VSIV-3 from cattle. In Sergipe (1984), ALONSO FERNANDES \& SÖNDAHL (1985) isolated a serotype VSIV-3 from horses.

In the last years, several outbreaks of VS have been reported in midwestern and northeastern (NE) Brazilian States (ROSENDO et al., 2013; CARGNELUTTI et al., 2014). Reports from the PANAFTOSA (2015) have also indicated viral activity in NE states in the last years. In 2013, outbreaks of VS were reported in horses and cattle in states of Paraiba and Rio Grande do Norte, with the identification of VSIV-3 (CARGNELUTTI et al., 2014).

Considering the sanitary and economical importance of the disease, this study was designed to investigate circulation of VSV-3, through serology, in horses from three Brazilian regions: Southern, Midwestern and Northeast.

\section{MATERIALS AND METHODS}

The present study used 3,626 serum samples from horses of three Brazilian regions: southern (Rio Grande do Sul [RS]), midwest (Goiás [GO] and Federal District $[\mathrm{DF}]$ ) and northeast (Pernambuco [PE], Paraíba [PB], Rio Grande do Norte [RN] and Ceará $[C E])$. Samples from northeast $(n=848)$ and midwest $(n=1,767)$ were from the official diagnosis of equine infectious anemia virus (EIAV) collected between 2013 and 2014. RS samples $(n=1,011)$ were collected in 2013, as a part of an official serological survey of EIA.

Serum samples were submitted to $\mathrm{VN}$ test for detection of antibodies to VSV, according to the OIE (2010) protocol, using the isolate VSIV-3 2013 SaoBento/ ParaibaE (CARGNELUTTI et al., 2014). After complement inactivation, serum samples were diluted 1:40 and incubated with 400-500 $\mathrm{TCID}_{50}$ of the isolate VSIV-3 2013 SaoBento/ParaibaE for $1 \mathrm{~h}$ at $37^{\circ} \mathrm{C}$, followed by addition of a suspension of Vero cells and incubation at $37^{\circ} \mathrm{C}$ with $5 \% \mathrm{CO}_{2}$. The cultures were monitored for citopathic effect (cpe) for $72 \mathrm{~h}$. Samples not presenting cpe were considered positive for VSV antibodies at the 
used dilution. Then, positive samples were submitted to a quantitative VN test, in which a fixed dose of virus (400$500 \mathrm{TCID}_{50}$ ) was incubated with serial 2-fold dilutions of sera, starting at 1:40. In this test, each sample was tested against three VSV strains/isolates: isolate $V S I V-3$ 2013SaoBento/Paraiba E, strain Indiana (VSIV-1) and VSNJV. After $72 \mathrm{~h}$, the cultures were monitored for cpe and the $\mathrm{VN}$ titers were considered as the reciprocal of the highest serum dilution capable to prevent cpe. Virus titers were transformed in GMT $\log _{2}$ (THRUSFIELD, 1986), considering 1:40 as the lowest dilution, and graded as low GMT $\left(\log _{2} \leq 3.0\right)$, moderate $\left(3.0<\right.$ GMT $\left.\log _{2} \leq 4.0\right)$ and high (GMT $\left.\log _{2}>4.0\right)$.

\section{RESULTS AND DISCUSSION}

Results of VN assays revealed the presence of neutralizing antibodies reacting with isolate $V S I V$ 32013 SaoBento/Paraiba $E$, in varied frequency and titers, in all three studied regions. The overall rate of seropositivity was $17.7 \%\left(\mathrm{CI}_{95 \%}: 16.5-19.0 \%\right)$, with the highest values observed in NE states (Table 1). High percentages of positive samples were observed in $\mathrm{CE}\left(87.3 \%: \mathrm{CI}_{95 \%}: 83.4-90.5 \%\right)$ and $\mathrm{RN}(65.7 \%$; $\left.\mathrm{CI}_{95 \%}: 57.8-72.7 \%\right)$; moderate rates in $\mathrm{PB}(45.4 \%$; $\left.\mathrm{CI}_{95 \%}: 39.4-51.5 \%\right)$; low levels in PE (8.7\%), GO/DF $\left(4.4 \% ; \mathrm{CI}_{95 \%}: 3.5-5.5 \%\right)$ and very low prevalence rates in $\mathrm{RS}\left(0.9 \% ; \mathrm{CI}_{95 \%}: 0.4-1.7 \%\right)$. Since no comercial VSV vaccines are available in Brazil (SINDAN, 2015), positive serological response is obviously due to a previous exposure to the virus, reflecting different levels of virus circulation in the three regions. These results indicated that $\mathrm{CE}, \mathrm{RN}$ and $\mathrm{PB}$ States presented a broader viral activity, in contrast with the viral circulation in the Midwest and Southern regions, whose immunological reaction probably reflects a low frequency and remote viral activity.
The high prevalence of VSV-3 antibodies in most NE states is compatible with the study by ALLENDE \& GERMANO (2003), who detected $91.5 \%(300 / 328)$ of seropositivity. Based upon these results, however, is difficult to estimate the real prevalence of VSV antibodies in the region since the Centro Panamericano de Febre Aftosa (PANAFTOSA) reports only cases notified from 2013 to the present. Nevertheless, several outbreaks/ cases of vesicular disease have been notified in the NE States in the last 10 years (OIE, 2010; CARGNELUTTI et al., 2014), from which several were confirmed as VS. Information by PANAFTOSA (2015) also indicated recent virus circulation in NE in the last years.

Moderate to high antibody prevalence in horses from NE states likely reflects the environmental conditions, especially the climate, which favors the maintenance of large populations of insects (especially mosquitoes), probable VSV vectors (BENNETT et al., 2008). Likewise, low frequency of VSV antibodies in RS (0.9\%) may be attributed, in part, to he climatic conditions that disfavor the maintenance of abundant insect populations. Low levels of antibodies in horses from RS likely reflect a timely remote exposure to VSIV-3 or related viruses. Similar findings have been reported for other arboviruses, such as Dengue, Bluetongue and EIAV, whose frequency in RS is markedly lower than that observed in central and northern States (MELLOR \& LEAKE, 2000). Regardless, VS cases have been reported in Santa Catarina, a southern state (LOPES et al., 1999).

After the initial screening with isolate VSIV-3 2013SaoBento/ParaibaE, positive samples were tested against VSIV-1 (Indiana) and VSNJV, trying to confirm the viral serotype involved. In RS,

Table 1 - Results of virus-neutralizing tests against vesicular stomatitis virus - VSIV-3 2013 SaoBento/ParaibaE - in sera of horses of different Brazilian States.

\begin{tabular}{|c|c|c|c|c|}
\hline State & Number & Positive $(\%)^{*}$ & Neutralizing titers $^{* *}$ & $\log _{2}$ \\
\hline Rio Grande do Sul & 1,011 & $9(0.9)$ & $40-160$ & 2.1 \\
\hline Goiás/Distrito Federal & 1,767 & $78(4.4)$ & $40-\geq 10240$ & 3.0 \\
\hline Pernambuco & 46 & $4(8.7)$ & $40-1280$ & 3.0 \\
\hline Paraíba & 273 & $124(45.4)$ & $40-\geq 10240$ & 4.5 \\
\hline Rio Grande do Norte & 166 & $109(65.7)$ & $40-\geq 10240$ & 3.8 \\
\hline Ceará & 363 & $317(87.3)$ & $40-\geq 10240$ & 4.4 \\
\hline Total & 3,626 & $641(17.7)$ & $40-=10240$ & 4.1 \\
\hline
\end{tabular}

Neutralizing titers $\geq 40$.

${ }^{* *}$ Reciprocal of the highest serum dilution capable to prevent the production of cytopathic effect.

Ciência Rural, v.46, n.8, ago, 2016. 
9 samples were also positive for VSIV-1 (titers from 40 to 160) and none reacted with VSNJV. In GO/ DF, 10 samples reacted with VSIV-1 (titers 40 to 80) and none with VSNJV. In NE states, 164 samples reacted with VSIV-1 (40 to 1280) and 7 reacted also with VSNJV (titer of 40). In spite of the antigenic differences between VSV serotypes, variable levels of cross-neutralization are observed among VSIV-1, 2 e 3 (PAUSZEK et al., 2011). In contrast, crossneutralization between VSIV and VSNJV occurs at very low levels due to their antigenic differences (CARTWRIGHT \& BROWN, 1972). Positivity to VSNJV is probably to this cross-reactivity because VSNJV is considered exotic in Brazil (OIE, 2010; PANAFTOSA, 2015). In summary, results of VN tests indicated that the neutralizing antibodies detected were probably produced in response to infection by viruses antigenically related to VSIV-3 (VSIV-3 2013SaoBento/ParaibaE), confirming the frequent circulation of this serotype in the region.
Unfortunately, we could not test the samples against VSV Cocal because we could not obtain a virus of this serotype. Thus, it can not be discarded that part of the samples that reacted with VSIV-3 2013 SaoBento/ParaibaE could be result from exposure to VSIV-2 Cocal, since there are reports indicating the circulation of this serotype in Brazil (REIS JR et al., 2009). In this sense, circulation of VSIV-2 seems to be more abundant in the Southeastern and Midwestern regions (LÓPEZ et al., 1996-1997).

Figure 1 presents the frequency and distribution of neutralizing titers by state. In NE states - PE is an exception - moderate titers (1601280) were more frequent, but high titers were also observed $(2560,5120,>10240)$. Moderate titers suggest a not recent exposure since high titers are usually observed within weeks or months after VSV infection (CARGNELUTTI et al., 2014). Moreover, high titers (2560 a $\geq 10240)$ indicate recent exposure. These findings agree with data by
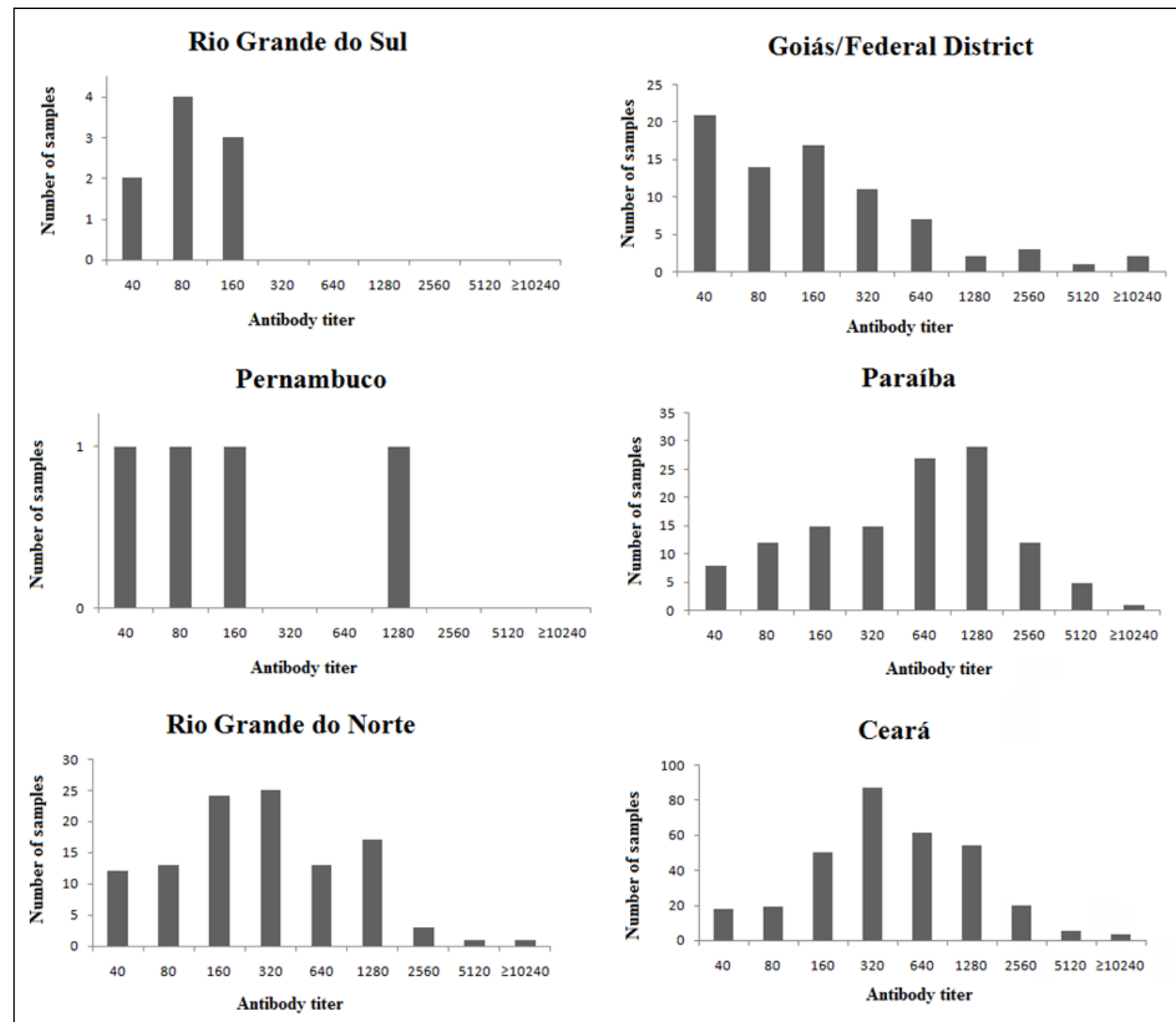

Figure 1 - Distribution of neutralizing antibody titers to VSIV-3 2013 SaoBento/Paraiba E in horses of different Brazilian States.

Ciência Rural, v.46, n.8, ago, 2016. 
PANAFTOSA (2015), which reported confirmed cases/outbreaks of VS in the region in the last years, including those reported by CARGNELUTTI et al. (2014). A similar distribution of virus titers, with predominant moderate titers $(160-1280)$ and some high titers $(\geq 2560)$ were observed in $\mathrm{GO} / \mathrm{DF}$, also suggesting recent exposure.

VSV infection is considered endemic in Brazilian northeastern States, where is probably under notified. The present results validate this status because they indicated the circulation of VSV - likely serotype 3 - in horses from this region. In addition, our work indicates a viral activity of lower intensity also in GO/DF. Residual antibodies were detected, probably reflecting remote past exposure to the virus in RS.

Because cattle is the most important host species for VSV infection - which it can be confounded with FMD, leading to serious sanitary consequences -, it would be interesting to investigate the presence and distribution of VSV antibodies in cattle of the studied regions. In this sense, a report by CARGNELUTTI et al. (2014) described VS cases predominantly in horses but also in cattle in northeastern States. In agreement with the latter work, our data indicates that VSV is already circulating in these regions.

\section{CONCLUSION}

Serologic data indicated the circulation of VSIV-3 (related to VSIV-3 2013SaoBento/ ParaibaE) in horses in NE States, presence in low levels in $\mathrm{GO} / \mathrm{DF}$ and residual levels of antibodies in RS, probably reflecting a timely remote virus circulation. Our results reinforce the sanitary importance of this infection, contributing for its understanding, notification and control.

\section{ACKNOWLEDGEMENTS}

This reserach was supported by Conselho Naciona de Desenvolvimento Científico e Tecnológico (CNPq). LUNKES, V.L. (131011/2014-6), FLORES,E.F. and WEIBLEN, R. are recipients of Conselho Nacional de Desenvolvimento Científico e Tecnológico (CNPq) fellowships.

\section{REFERENCES}

ALLENDE, R.; GERMANO, P.M.L. Comparison of virus neutralisation and enzime-linked immunosorbent assay for the identification of antibodies against vesicular stomatitis (Indiana 3) virus. Revue Scientifique et Technique (International Office of Epizootics), v.12, p.849-855, 1993. Available from: $<$ http://www. oie.int/doc/ged/D8756.PDF>. Accessed: Feb. 07, 2015
ALONSO FERNANDEZ, A. et al. Development and evaluation of an enzime-linked immunosorbent assay for the detection, typing and subtyping of vesicular stomatitis virus. Journal of Veterinary Diagnostic Information, v.3, p.287-292, 1991. Available from: $<$ http://vdi.sagepub.com/content/3/4/287.full.pdf + html $>$. Accessed: Feb. 11, 2015. doi: 10.1177/104063879100300403.

ALONSO FERNANDEZ, A.; SÖNDAHL, M.S. Caracterizacion antigenica e inmunogenica de varias cepas del sorotipo Indiana de estomatitis vesicular aisladas en Brasil. Boletín del Centro Panamericano de Fiebre Aftosa, v.51, p.23-26, 1985.

ANDRADE, C.M. et al. Vesicular stomatitis in Brazil I - Isolation and identification of the Alagoas strain. Anais de microbiologia, v. 25, p.81-87, 1980 .

ARAÚJO, M.L.R. et al. Isolamento do vírus da Estomatite Vesicular tipo Indiana, subtipo Indiana III no Estado de Minas Gerais, Brasil. Arquivos da Escola Veterinária da Universidade Federal de Minas Gerais, v.29, p.185-189, 1977.

BENNETT, K.E. et al. Blood-feeding behavior of vesicular stomatitis virus infected Culicoides sonorensis (Diptera: Ceratopogonidae). Journal of Medical Entomology, v.45, p.921-926, 2008. Available from: <http://jme.oxfordjournals. org/content/45/5/921.long $>$. Accessed: Feb. 11, 2015. doi: 10.1603/0022-2585(2008)45[921:BBOVSV]2.0.CO;2

CARGNELUTTI, J.F. et al. Outbreaks of vesicular stomatitis Alagoas virus in horses and cattle in northeastern Brazil. Journal of Veterinary Diagnostic Information, v.26, p.788-794, 2014. Available from: <http://vdi.sagepub.com/content/26/6/788.long>. Accessed: Feb. 11, 2015. doi: 10.1177/1040638714553428.

CARTWRIGHT, B.; BROWN, F. Serological relationships between different strains of vesicular stomatis virus. Journal of General Virology, v.16, p.391-398, 1972. Available from: <http://vir.sgmjournals.org/content/16/3/391.full.pdf $>$. Accessed: Apr. 08, 2015.

CUNHA, E.M.S. et al. Seroprevalence of viral diseases in equidae from the south of São Paulo state, Brazil. Arquivos do Instituto Biológico, v.76, p.165-171, 2009. Available from: $<$ http://www.biologico.sp.gov.br/docs/arq/v76_2/cunha2.pdf $>$. Accessed: Feb. 11, 2015.

FERRIS, N.P.; DONALDSON, A.I. An enzyme-linked immunosorbent assay for the detection of vesicular stomatitis virus antigen. Veterinary Microbiology, v.18, p.243-258, 1998.

HAYEK, A.M. et al. Financial impact of the 1995 outbreak of vesicular stomatitis on 16 beef ranches in Colorado. Journal of American Veterinary Medical Association, v.212, n.6, p.820-823, 1998.

ICTV. ICTV Virus Taxonomy 2014. Virus taxonomy: 2014 Release. Edinburgh, jul. 2014. Online. Available from: $<$ http:// ictvonline.org/virusTaxonomy.asp>. Accessed: Feb. 07, 2015.

LETCHWORTH, G.J. et al. Vesicular stomatitis. Veterinary Journal, v.157, p.239-260, 1999. Available from: $<$ http://www. sciencedirect.com/science/article/pii/S1090023398903033>. Accessed: Feb. 11, 2015. doi: 10.1053/tvj1.1998.0303.

LOPES, S.S. et al. Caso de estomatite vesicular em bovinos na área livre de febre aftosa com vacinação. In: CONGRESSO 
BRASILEIRO DE BUIATRIA, 3, 1999, São Paulo, SP. Arquivos Instituto Biológico, v.66, p.128, 1999.

LÓPEZ, I.A. et al. Distribuición histórica de la estomatitis vesicular en Brasil. Boletim del Centro Panamericano de Fiebre Aftosa, v.62-63, n.1, p.10-20, 1996-1997. Available from: <http:// bvs1.panaftosa.org.br/local/file/textoc/Boletin62-62-Lopez-esp. pdf>. Accessed: Feb. 11, 2015.

MASON, J. Epidemiologia de la stomatitis vesicular. Boletim del Centro Panamericano de Fiebre Aftosa, v.29-30, n.1, p.1333, 1978. Available from: <http://www.fmvz.unam.mx/fmvz/ cienciavet/revistas/CVvol2/CVv2c4.pdf>. Accessed: Nov. 09, 2015.

MELLOR, P.S.; LEAKE, C.J. Climatic and geographic influences on arboviral infections and vectors. Revue scientifique et technique (International Office of Epizootics), v.19, p.41-54, 2000. Available from: <http://www.oie.int/doc/ged/d9286.pdf> Accessed: Feb. 11, 2015.

OIE. VESICULAR STOMATITIS. OIE Terrestrial Manual 2010, 1 may. 2010. Online. Available from: <http://www. oie.int/fileadmin/Home/eng/Health_standards/tahm/2.01.19 VESICULAR STOMITIS.pdf $>$. Accessed: Feb. 11, 2015.

OKUDA, L.H. et al. Vesicular stomatitis: monitoring in semen donor bulls of an artificial insemination center. Arquivos do Instituto Biológico, v.70, p.11-15, 2003. Available from: $<\mathrm{http}: /$ www.biologico.sp.gov.br/docs/arq/V70_1/okuda.pdf $>$. Accessed: Feb. 11, 2015.

PANAFTOSA. Informes PANAFTOSA. Listserv 16.0, 1 may. 2010. Accessed: Feb. 11, 2015. Online. Available from: $<$ http://listserv.paho.org/scripts/wa.exe?A0=INFORMESPANAFTOSA $>$.
PAUSZEK, S.J. et al. Genetic and antigenic relationships of vesicular stomatitis viruses from South America. Archives of Virology, v.156, n.11, p.1961-1968, 2011. Available from: <http:// dx.doi.org/10.1007/s00705-011-1081-1>. Accessed: Apr. 08, 2015. doi: 10.1007/s00705-011-1081-1.

REIS JR, J.L. et al. Transmission and pathogenesis of vesicular stomatitis virus. Brazilian Journal of Veterinary Pathology, v.2, n.1, p.49-58, 2009. Available from: <http://bjvp.org.br/wpcontent/uploads/2015/07/V.2-N.1-12-20881_2009_12_30_29_6. pdf>. Accessed: Apr. 08, 2015.

RIET-CORREA, F. et al. Viral diseases to be differentiated from foot-and-mouth disease. Ciência Rural, v.26, n.2, p.323332, 1996. Available from: <http://dx.doi.org/10.1590/S010384781996000200027>. Accessed: Nov. 09, 2015. doi: 10.1590/ S0103-84781996000200027.

ROSENDO, A.R.G.V. et al. Estomatite vesicular no município Umarizal, estado do Rio Grande do Norte, Brasil. Revista de Educação Continuada em Medicina Veterinária e Zootecnia, v.11, n.3, p.57-57, 2013. Available from: <http://revistas.bvs-vet. org.br/recmvz/article/view/19563/20401>. Accessed: Feb. 11, 2015.

SINDAN. CPVS. Compêndio de Produtos Veterinários, s.1., 11 fev 2015. Accessed: Feb. 11, 2015. Online. Available from: $<$ http://www.cpvs.com.br/cpvs/pesquisar.aspx $>$.

TESH, R.B. et al. Ecologic studies of vesicular stomatitis virus. American Journal of Epidemiology, v.91, p.216-224, 1970. Available from: <http://aje.oxfordjournals.org/content/91/2/216. long>. Accessed: Apr. 08, 2015.

THRUSFIELD, M.V. Serological epidemiology. In: Veterinary epidemiology. London: Butterworths, 1986. Cap.16, p.175-186. 